\title{
Disruptive innovations
}

\author{
Giampaolo Viglia ${ }^{1}$ (D) Hannes Werthner ${ }^{2} \cdot$ \\ Dimitrios Buhalis ${ }^{1}$
}

Received: 14 November 2016/ Accepted: 15 November 2016/Published online: 23 November 2016

(C) Springer-Verlag Berlin Heidelberg 2016

\section{Introduction}

The diffusion of disrupting innovations has generated significant market changes, modifying the dominant logic and affecting the strategic positioning of companies. This structural change is affecting market structure, the networks and the services that tourism players are supposed to use (Gretzel et al. 2015). One can also refer to the notion of digital infrastructure, which provides a nice framework that connects the different stakeholders, their relations as well as internal dynamics. At the end it is about increasing customer experience, improving market performance, reducing inefficiency and-equally important-providing open access to the electronic market. Remember: this was one of biggest hopes at the beginning of the Web, which already seems centuries ago.

Innovations are an essential component of tourism and hospitality industries (Sipe 2016). In this domain, disruptive changes affect several aspects as well as relationships between players change, as their respective roles change. All this is possible thanks to technological smart e-platforms. For instance, hotels can now use algorithms to set yield and revenue management strategies, monitor competition in real time (Abrate and Viglia 2016) and allow consumers to use mobile devices to access several services (Buhalis and Foerste 2015).

Many innovations have been initiated from companies in the information technology sector. One can even state, that innovation is coming from outside, where information technology is revolutionizing products and services. Take as a

\footnotetext{
Giampaolo Viglia

giampaolo.viglia@gmail.com

1 Bournemouth University, Poole, UK

2 Vienna University of Technology, Vienna, Austria
} 
latest example the growth of peer-to-peer platforms like in the case of the sharing economy (Guttentag 2015; Wang et al. 2016).

The aim of this special issue is (a) to provide a platform for the dissemination of findings from studies that combine elements of IT-based innovation and tourism, and (b) to take up one of the major challenges of the JITT research manifesto, i.e., understanding and reflecting on structural market changes (Werthner et al. 2015). The papers in this issue provide new theoretical and empirical research on how and why the changes happened (theory building), as well as providing empirical observations to study the phenomenon.

In the first paper, Gregorash discusses how to maximise the revenues per available seat hour (RevPASH) in restaurants. The study empirically assesses the premium revenue level that can be achieved through reservation systems that take advantage of seating plans with respect to walk-in strategies. The theme of smart revenue management continues with Digiorgio, who focuses on accommodation facilities. Her paper, with an empirical analysis with more than 1000 establishments, shows which digital tools can help to decrease the dependence from Online Travel Agencies (OTAs). Rebalancing the exposure to OTAs is relevant for hotels, given the high commissions that hospitality operators have to pay to OTAs. Further evidence by Cetin, Cifci, Dincer and Fuchs confirms the intricate and unbalanced power between OTAs and small and medium sized independent hotels.

Drawing from the theoretical frameworks of disruptive innovation and smart tourism ecosystems, the sharing economy realm is central in Tham's contribution. The author discusses the adoption of Airbnb and Uber across different countries, underlying the need for a unified legislation. In the fifth paper, Yang-chan Hsu, King, Wang and Buhalis explore the role of new emerging competitors that have embraced technology-enabled innovations. These new players have challenged established inbound tour operators, interacting directly with customers through e-platforms. The authors adopt a multiple case study approach and assemble evidence from 17 examples of tourism start-ups in Taiwan.

In the final paper, Gon, Pechlaner and Marangon investigate how Digital Natives (Dns) engage with destination management organization through social media. The findings from the paper suggest the importance of focusing on the informal expertise of DNs in the planning and development of digital strategies for destination management organizations.

Guest Editors

Dr. Giampaolo Viglia

Prof. Hannes Werthner

Prof. Dimitrios Buhalis

\section{References}

Abrate G, Viglia G (2016) Strategic and tactical price decisions in hotel revenue management. Tour Manag 55:123-132 
Buhalis D, Foerste M (2015) SoCoMo marketing for travel and tourism: empowering co-creation of value. J Destin Mark Manag 4(3):151-161

Gretzel U, Werthner H, Koo C, Lamsfus C (2015) Conceptual foundations for understanding smart tourism ecosystems. Comput Hum Behav 50:558-563

Guttentag D (2015) Airbnb: disruptive innovation and the rise of an informal tourism accommodation sector. Curr Issues Tour 18(12):1192-1217

Sipe LJ (2016) How do senior managers influence experience innovation? Insights from a hospitality marketplace. Int J Hosp Manag 54:75-83

Wang D, Li M, Guo P, Xu W (2016) The impact of sharing economy on the diversification of tourism products: implications for tourist experience. Inf Commun Technol Tour. Springer, pp 683-694

Werthner H, Alzua-Sorzabal A, Cantoni L, Dickinger D, Gretzel U, Jannach D, Neidhardt J, Pröll B, Ricci R, Scaglione M, Stangl B, Stock O, Zanker M (2015) Future research issues in IT and tourism. Inf Technol Tour 15:1 